\title{
Effect of temperature and species of plant on the consumption of leaves by three species of Orthoptera under laboratory conditions
}

\author{
Spyridon A. ANTONATOS ${ }^{1,2}$, Nikolaos G. EMMANUEL ${ }^{2}$ and Argyro A. FANTINOU 3 \\ ${ }^{1}$ Laboratory of Agricultural Entomology, Department of Entomology and Agricultural Zoology, Benaki Phytopathological Institute, \\ Stefanou Delta 8, 14561 Kifissia, Greece; e-mail: s.antonatos@bpi.gr \\ ${ }^{2}$ Laboratory of Agricultural Zoology and Entomology, Agricultural University of Athens, Iera Odos 75, 11855 Athens, Greece; \\ e-mail: ceaz2emn@aua.gr \\ ${ }^{3}$ Laboratory of Ecology and Environmental Science, Agricultural University of Athens, Iera Odos 75, 11855 Athens, Greece; \\ e-mail: argyr@aua.gr
}

Key words. Orthoptera, Calliptamus barbarus barbarus, Dociostaurus maroccanus, Tettigonia viridissima, leaf area consumption

\begin{abstract}
In the Mediterranean area the orthopterans Calliptamus barbarus barbarus, Dociostaurus maroccanus and Tettigonia viridissima are considered to be pests of major economic importance crop plants. The aim of the present study was to evaluate the area of leaf of vine, cotton and potato plants consumed by these Orthoptera at two temperatures. Leaf area was determined for each plant species before the leaves were provided to the insects. Virgin male and female adults were allowed to feed on a leaf of each plant species and the area of leaf consumed was determined after $24 \mathrm{~h}$ at 25 and $30^{\circ} \mathrm{C}$. Results showed that temperature had a significant affect on consumption by both males and females of all the species examined, and it was higher at $30^{\circ} \mathrm{C}$. The influence of plant species was not significant for C. barbarus barbarus. D. maroccanus and T. viridissima, however, consumed a greater area of potato leaves than of the other species of plants. Females consumed more food than males in all the species tested. The results of the present study provide a first approximation of the area of leaf consumed and the potential loss of foliage these plants might suffer if attacked by the three species of Orthoptera tested.
\end{abstract}

\section{INTRODUCTION}

Orthoptera are well known for their herbivory and generally regarded as a dominant insect group in most terrestrial habitats. They feed on all types of plants and often cause important economic damage. In the Temperate Zone, the relatively high diversity and density of Orthoptera in grasslands (Ryszkowski et al., 1993; Szövènyi, 2002) consume annually about $3-5 \%$ of the plant production in these habitats (Ingrisch \& Köhler, 1998). Orthoptera can feed on many kinds of vegetation and are often recorded causing considerable damage to crops, such as cereals, fabaceous plants, vegetables, industrial crops and fruit trees in several areas of the world (Smith \& Holmes, 1977; Jonson \& Mündel, 1987; Shower, 1995; Latchininsky, 1998; Riffat \& Wagan, 2007; Blanchet at al., 2010).

Over 390 species of Orthoptera are known to occur in Greece (Willemse \& Willemse, 2008), but only a few of them damage crops. Among the most common species causing serious damage to crops in Greece and other Mediterranean countries are Dociostaurus maroccanus (Thunberg, 1815), species of the genus Calliptamus and Tettigonia viridissima (Linnaeus, 1758) (Pelekasis, 1976; Latchininsky, 1998; Blanchet et al., 2010, 2012). D. maroccanus is highly polyphagous and exhibits extremely voracious feeding on more than 150 plant species belonging to 33 families, including many crop plants (Latchininsky, 1998). Calliptamus barbarus barbarus (Costa, 1836) along with the closely related Calliptamus italicus (Linnaeus, 1758) are also highly polyphagous.
They can feed on a broad spectrum of plants belonging to the families Compositae, Papilionaceae, Malvaceae, Poaceae, Fabaceae, Solanaceae, Cruciferae as well as many vegetables and fruit trees (Bei-Bienko \& Mischenko, 1963). T. viridissima is a serious pest of cereals, potatoes, grape vines and other annual crops (Gentry, 1965; Pelekasis, 1976).

Among the most important crop plants in Greece are vine, cotton and potato. According to Faostat (2012) the estimated areas of these three crops in 2010 were 99,300, 250,000 and 31,400 ha, respectively. Every year these crops suffer severe losses of yield as a result of orthopteran infestations. Several areas in Greece are regularly infested by grasshoppers and sprayed with insecticides.

Although there are several studies on the feeding habits and food consumption of various orthopteroid species (Bailey \& Mukerji, 1976; Hoekstra \& Beenakkers, 1976; Jonson \& Mündel, 1987; Akman-Gündüz \& Gülel, 2002; Bardi et al., 2011; Mariottini et al., 2011; Syed et al., 2011) there are no relevant reports for Greece. On the other hand most of the data on the feeding rate of Orthoptera are records for one temperature although it is well known that insect food intake is temperature dependent (Ferro et al., 1985; Logan et al., 1985). Accurate estimates of the consumption and voracity of Orthoptera are required for determining their potential effect and the economic consequences of defoliation by these insects (Pedigo et al., 1986).

In the study reported here we compare the area of leaf of vine, cotton and potato consumed by three species of 
Orthoptera at two temperatures under laboratory conditions. This research focused on $C$. barbarus barbarus (Caelifera: Acrididae), D. maroccanus (Caelifera: Acrididae) and T. viridissima (Ensifera: Tettigoniidae) because they are serious pests of crops in the Mediterranean area.

\section{MATERIAL AND METHODS}

Last instars nymphs of all three species were collected by sweep netting in a lowland grassland area near Spata (Attica Greece) (Evans et al., 1983) in the spring of 2009. After collection the insects were transferred to the laboratory and reared in wooden framed cages at a temperature of $25 \pm 1{ }^{\circ} \mathrm{C}$, humidity 65 $\pm 5 \%$ and under a photoperiod 16L : 8D (Lactin \& Johnson, 1995; De Faria et al., 1999). Insects were fed lettuce leaves and supplied with water in a piece of water soaked cotton placed at the bottom of each cage until adult emergence. Lettuce leaves were replaced daily. 20-30 nymphs of either $C$. barbarus barbarus or D. maroccanus were placed in each cage $(30 \times 30 \times 30$ $\mathrm{cm})$. For $T$. viridissima 2-3 nymphs were placed in smaller cages $(20 \times 20 \times 20 \mathrm{~cm})$ as mature instars eat the younger ones. On the day of emergence male and female adults were separated based on their morphological characteristics. These adults were kept in cages of the same dimensions and fed lettuce leaves until used in feeding bioassays. In all the experiments 5 to 15 day old virgin female and male insects were used.

Adults used in experiments were transferred and placed individually in glass cages $13 \mathrm{~cm}$ in diameter and $15 \mathrm{~cm}$ high, with the opening at the top covered with fine muslin. The cages were placed in chambers in which the humidity was $65 \pm 5 \%$ and kept at one of two temperatures. Cool fluorescent light provided a photoperiod of $16 \mathrm{~L}: 8 \mathrm{D}$. In each cage one fully expanded
TABLE 1. Mean weight $(\mathrm{mg}) \pm$ standard error of the males and females of the three species of Orthoptera tested.

\begin{tabular}{lcc}
\hline Orthoptera species & Male & Female \\
\hline Calliptamus barbarus barbarus & $210 \pm 10 \mathrm{~b}$ & $980 \pm 30 \mathrm{a}$ \\
Dociostaurus maroccanus & $260 \pm 10 \mathrm{~b}$ & $610 \pm 20 \mathrm{a}$ \\
Tettigonia viridissima & $960 \pm 40 \mathrm{~b}$ & $1630 \pm 60 \mathrm{a}$ \\
\hline
\end{tabular}

Means on the same line that are followed by different letters differ significantly (t-test: $\mathrm{P}<0.05$ ).

mature leaf of vine, cotton or potato of approximately $100 \mathrm{~cm}^{2}$ in area was placed with its stem in a vial of water to keep it turgid. Water was provided for the insects in a piece of water soaked cotton placed at the bottom of each cage. Leaves of vine, cotton and potato varieties, sultanina, cellia and spunta, respectively, were offered to the insects. The vine leaves were collected from a vineyard of the Agricultural University of Athens (AUA). No pesticides were used in the vineyard. Potato and cotton plants were grown from seed in pots of $30 \mathrm{~cm}$ diameter containing compost kept in an open area at the AUA and no pesticides were used. The area of each leaf provided to the insects was measured by scanning the area of the leaf using a computer and software Delta-T SCAN (Version 2.04nc, Delta-T Devices Ltd., Burwell, Cambridge, UK). Insects were permitted to feed for $24 \mathrm{~h}$ and then removed and the area of leaf consumed by each individual was determined by measuring the area of the leaf again (Shields et al., 1985; Ávila \& Parra, 2003). Insects that became less active during or after testing were replaced and the measurements for these insects were not included in the analysis. In addition, if the lamina of the leaf was cut from the stem the measurement was also not included in the analysis.

TABLE 2. Summary of ANOVA results for the effects of temperature, plant species and sex of insect and their interactions on the area of leaf consumed by the three species of Orthoptera tested.

\begin{tabular}{|c|c|c|c|c|}
\hline Orthoptera species & & $d f$ & $F$ & $P$ \\
\hline \multirow{7}{*}{$\begin{array}{c}\text { Calliptamus } \\
\text { barbarus } \\
\text { barbarus }\end{array}$} & Temperature & 1,158 & 51.79 & $<0.0001^{*}$ \\
\hline & Plant species & 2,158 & 0.06 & 0.9415 \\
\hline & Sex of insect & 1,158 & 999.77 & $<0.0001^{*}$ \\
\hline & Temp. $\times$ Pl.sp & 2,158 & 1.16 & 0.3173 \\
\hline & Temp. $\times$ Ins.sex & 1,158 & 7.60 & $0.0065^{*}$ \\
\hline & Pl.sp. $\times$ Ins.sex & 2,158 & 1.62 & 0.2131 \\
\hline & Temp. $\times$ Pl.sp. $\times$ Ins.sex & 2,158 & 0.80 & 0.4508 \\
\hline \multirow{7}{*}{$\begin{array}{c}\text { Dociostaurus } \\
\text { maroccanus }\end{array}$} & Temperature & 1,159 & 38.35 & $<0.0001 *$ \\
\hline & Plant species & 2,159 & 65.46 & $<0.0001 *$ \\
\hline & Sex of insect & 1,159 & 196.45 & $<0.0001 *$ \\
\hline & Temp. $\times$ Pl.sp & 2,159 & 0.07 & 0.9319 \\
\hline & Temp. $\times$ Ins.sex & 1,159 & 0.29 & 0.5874 \\
\hline & Pl.sp. $\times$ Ins.sex & 2,159 & 4.88 & $0.0087^{*}$ \\
\hline & Temp. $\times$ Pl.sp. $\times$ Ins.sex & 2,159 & 0.56 & 0.5736 \\
\hline \multirow{7}{*}{$\begin{array}{l}\text { Tettigonia } \\
\text { viridissima }\end{array}$} & Temperature & 1,168 & 44.16 & $<0.0001 *$ \\
\hline & Plant species & 2,168 & 191.91 & $<0.0001 *$ \\
\hline & Sex of insect & 1,168 & 156.81 & $<0.0001 *$ \\
\hline & Temp. $\times$ Pl.sp & 2,168 & 0.67 & 0.5117 \\
\hline & Temp. $\times$ Ins.sex & 1,168 & 1.61 & 0.2067 \\
\hline & Pl.sp. $\times$ Ins.sex & 2,168 & 0.36 & 0.6949 \\
\hline & Temp. $\times$ Pl.sp. $\times$ Ins.sex & 2,168 & 1.06 & 0.3489 \\
\hline
\end{tabular}

* significant at $\mathrm{P}=0.05$, Temp. - temperature, Pl.sp. - plant species, Ins.sex - sex of insect. 


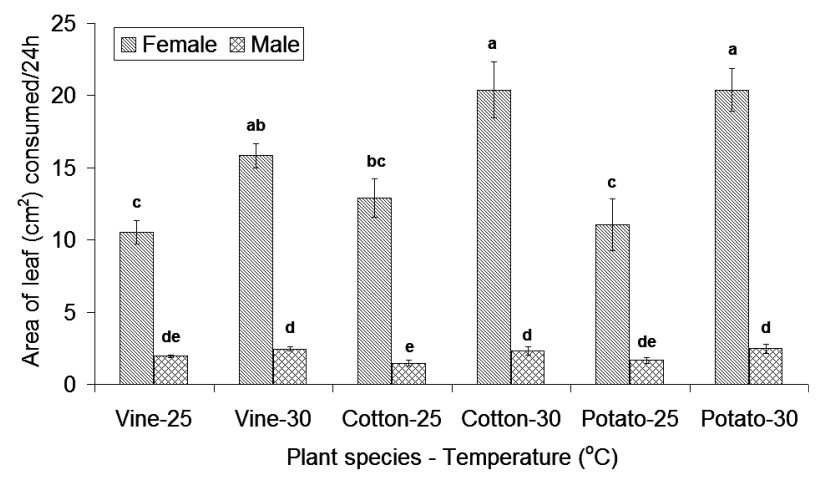

Fig. 1. Mean \pm standard error of the area of leaf $\left(\mathrm{cm}^{2}\right)$ consumed daily by adult female and male Calliptamus barbarus barbarus. Bars followed by different letters differ significantly (LSMeans Differences Student's test: $\mathrm{P}<0.05$ ).

Leaf consumption by male and female individuals of each of the three species of Orthoptera and of each crop plant (vine, cotton and potato) was determined at two temperatures, 25 and $30^{\circ} \mathrm{C}$ (12 treatments). There were mostly 15 replicates of each treatment but in a few cases only 13 or 14 replicates. In these experiments 170 individuals $\left(87 \%, 83 \sigma^{*}\right)$ of $C$. barbarus barbarus, 171 individuals $\left(89+, 82{ }^{\star}\right)$ of D. maroccanus and 180

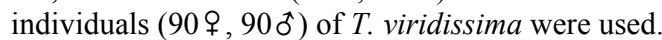

Leaf water content was determined by weighing 50 fresh leaves of each plant, drying them in an oven at $70^{\circ} \mathrm{C}$ for 5 days and then weighing them again (De Faria et al., 1999). The difference between the two measurements is the water content of each of the leaves. Mean weight of each of the species of Orthoptera tested was estimated by weighing 20 individuals of each species and sex before their use in the experiments.

The data on the consumption for the different species of Orthoptera were analyzed using three-way ANOVA with sex of the insect, temperature and plant species as factors. Comparisons of means were made using the criterion LSMeans Differences Student's and a $\mathrm{P}=0.05$. Before analysis data were transformed using $\mathrm{x}_{\text {trans }}=\log _{10}(\mathrm{x}+1)$ in order to homogenize variances and meet normality requirements. The body weights of male and female insects of each species were compared using $\mathrm{t}$-tests and a $\mathrm{P}=0.05$. The statistical software used in all the analysis was JMP 7.0.1 (SAS Institute Inc., 2007).

\section{RESULTS}

Mean leaf water content of the leaves of the three plants was $75.25 \pm 0.49 \%, 78.86 \pm 0.59 \%$ and $89.22 \pm 0.24 \%$, for vine, cotton and potato, respectively. Mean weight of the three species of Orthoptera is presented in Table 1. Females were heavier than males in all three species $(C$. barbarus barbarus, $d f=38, \mathrm{t}=-25.07, \mathrm{P}<0.0001 ; D$. maroccanus, $d f=38, \mathrm{t}=-16.17, \mathrm{P}<0.0001 ; T$. viridissima, $d f=38, \mathrm{t}=-9.61, \mathrm{P}<0.0001)$. The ANOVA results for the effects of plant species, sex of insect and temperature on the area of leaf consumed as well as their interactions for each of the species of Orthoptera studied are presented in Table 2.

\section{C. barbarus barbarus}

The temperature and sex of insect had a significant effect on the area of leaf consumed by C. barbarus barbarus. The species of plant had no significant effect on the area of leaf consumed by this species whereas there

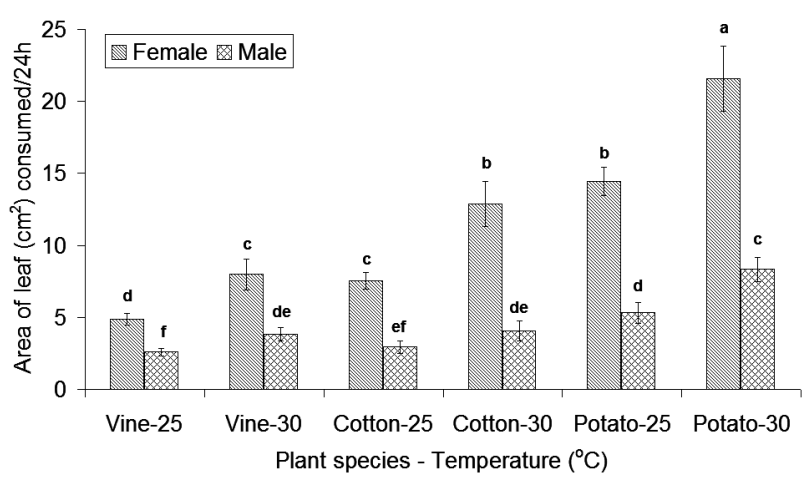

Fig. 2. Mean \pm standard error of the area of leaf $\left(\mathrm{cm}^{2}\right)$ consumed daily by adult female and male Dociostaurus maroccanus. Bars followed by different letters differ significantly (LSMeans Differences Student's test: $\mathrm{P}<0.05$ ).

was a significant interaction between temperature and sex of insect showing that temperature differentially affected females and males of this species (Table 2). The mean daily area of leaf consumed by an adult female and male of $C$. barbarus barbarus is shown in Fig. 1. Females consumed a larger area of leaf than males of each of the plants tested at both temperatures. The area of leaf of all the plants tested consumed by females was greater at 30 than at $25^{\circ} \mathrm{C}$. For males, only the consumption of cotton leaves was higher at 30 than at $25^{\circ} \mathrm{C}$. The three plant species were similarly consumed by the males and females (Fig. 1)

\section{D. maroccanus}

The consumption of $D$. maroccanus was significantly affected by the temperature, plant species and sex of the insect. A significant interaction between plant species and the sex of the insect was also recorded, indicating that consumption was dependent on the sex of the species (Table 2). The mean area of leaf consumed daily by adult female and male D. maroccanus is shown in Fig. 2. Females consumed a greater area of leaf than males in all the experiments regardless of the temperature and species of plant. They also consumed a larger area of leaf of all the three species of plant offered at $30^{\circ} \mathrm{C}$ than at $25^{\circ} \mathrm{C}$. Mean area of leaf of vine and potato consumed by males was different at the two temperatures, being larger at $30^{\circ} \mathrm{C}$ in both cases. However, no difference in consumption between the two temperatures was recorded when cotton leaves were offered to the male insects. A greater area of leaf of potato than of cotton and vine was consumed by both females and males at both temperatures. Of the cotton and vine females of $D$. maroccanus consumed a greater area of cotton leaves, but there were no differences in the consumption by males of the leaves of these two plants at the temperatures tested (Fig. 2).

\section{T. viridissima}

Temperature, plant species and sex of the insect had a significant effect on the area of leaf consumed by individuals of this species. No significant interactions between the main effects were recorded (Table 2). The mean area of leaf consumed daily by a female and male 


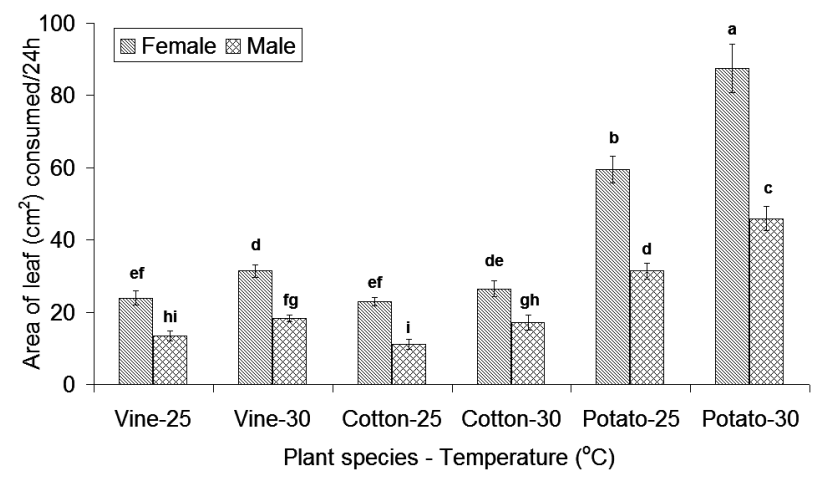

Fig. 3. Mean \pm standard error of the area of leaf $\left(\mathrm{cm}^{2}\right)$ consumed daily by adult female and male Tettigonia viridissima. Bars followed by different letters differ significantly (LSMeans Differences Student's test: $\mathrm{P}<0.05$ ).

adult of $T$. viridissima is shown in Fig. 3. The mean area of leaf consumed was always different for the sexes with females consuming greater areas of leaves than males of each plant at both temperatures. Consumption of vine and potato leaves by females was greater at $30^{\circ} \mathrm{C}$ than at $25^{\circ} \mathrm{C}$, while the consumption of cotton leaves did not differ between the two temperatures. The consumption of the leaves of all the species of plants by males was greater at $30^{\circ} \mathrm{C}$ than at $25^{\circ} \mathrm{C}$. The consumption of potato leaves by both females and males was greater than that of the other two plant species. No differences were recorded in the consumption of vine and cotton leaves at 25 and $30^{\circ} \mathrm{C}$ for either of the sexes (Fig. 3).

\section{DISCUSSION}

Temperature is one of the most important environmental factors affecting nearly all the physiological and biological processes in insects (Milonas \& SavopoulouSoultani, 2000; Wang \& Tsai, 2000). These processes depend on temperature-dependent chemical reactions that have a lower and upper temperature threshold (Sharpe et al., 1977). A rise in temperature generally increases the rates of metabolism, growth and feeding in insects (Wigglesworth, 1974; Levesque et al., 2002). The results obtained in this study showed that an increase in temperature had a positive effect on the area of leaf consumed by male and female insects in most of the cases examined. Orthoptera, like all insects, are poikilothermic, implying that they are affected by the ambient temperature. Between certain limits, rates of the different orthopterans activities increase with increase in body temperature (Begon, 1983; Whitman, 1986; Lactin \& Jonson, 1995; Willott \& Hassall, 1998). For most species of Orthoptera moderately high air temperatures $\left(25^{\circ} \mathrm{C}\right)$ are far below their optimum for development (Begon, 1983). Thus, an increase in temperature from 25 to $30^{\circ} \mathrm{C}$ should result in an increase in the area of leaf they consume. Our findings are in accordance with those of Lactin \& Jonson (1995) who report that the feeding rate of nymphs of Melanoplus sanguinipes (Fabricius, 1798) increases with temperature until it reaches the optimum for feeding, which is $35-40^{\circ} \mathrm{C}$.
The results presented indicate that there were no significant differences in the area of leaf of the three plant species consumed by males and females of $C$. barbarus barbarus. In contrast, both $D$. maroccanus and $T$. viridissima consumed a greater area of leaves of potato than of the other plants. Bernays \& Chapman (1977) studied the effect of more than 100 chemicals obtained from plant material on the feeding behaviour of Locusta migratoria migratorioides (Fairmaire \& Reiche, 1849). According to their results the presence of alkaloids or monoterpenoids in plant leaves results in a decrease in the amount of food eaten by this species. Vine and cotton leaves contain various terpenoids (Bell, 1986; Deliorman-Orhan et al., 2009). Consequently it is possible these chemicals may be the cause of the reduced feeding rate of $D$. maroccanus and $T$. viridissima recorded when provided with vine and cotton leaves. On the other hand, Cook (1977) reports that some plant species, which contain hexoses or disaccharide sugars, can stimulate feeding in some species of Orthoptera. Potato leaves contain $1.90 \%, 2.92 \%$ and $2.80 \%$, respectively, of glucose, fructose and sucrose (Kolbe \& Stephan-Beckmann, 1997a, b). Thus, the increased feeding recorded on this host by the two of the three species of Orthoptera tested may be related to the presence of these substances in potato leaves. Furthermore, McKinley \& Randell (1971) report that grasshoppers consume more food (fresh leaves) when fed on a diet with a high than a low moisture content. The lower water content of cotton and vine leaves, $11 \%$ and $14 \%$ less than potato leaves, respectively, could also have resulted in the greater areas of potato leaves consumed by $D$. maroccanus and $T$. viridissima.

The results showed that females consumed a greater area of leaf material than males in all the species of Orthoptera studied. This is also reported in other studies on Orthoptera (Johnson \& Pavlikova, 1986; Johnson \& Mündel, 1987; Mariottini et al., 2011). The body weight of the females of the three species used in the present study was greater than that of the males (Table 1). Holmberg \& Hardman (1984) report a strong correlation between food consumption and body weight in six species of grasshopper. Moreover virgin females of most species of Orthoptera produce a few eggs, which have a lower hatching success and the hatchlings suffer a higher mortality than those produced by mated females (Schmidt \& Albutz, 1994; Chapman, 1998; Walker et al., 1999). Initiation of vitellogenesis fails when the quantity of food ingested is low (McCaffery, 1975). Thus, in addition to the differences in body weights of males and females the nutritional requirements for oogenesis possibly drive the greater food consumption of female insects. Furthermore, these sex-related differences in nutritional requirements combined with differences in the food quality of different plants may lead, in some cases, to the different feeding responses of males and females of the same species and consequently to the interaction of the main effects.

The results of the present study provide an estimate of the area of leaf consumed and potential loss of yield of particular crop plants when attacked by Orthoptera. How- 
ever, it is also important to have a measure of the population density (number of individuals $/ \mathrm{m}^{2}$ ) of the orthopteroid species (Hewitt \& Onsager, 1983) and mean environmental temperature for an accurate estimate of crop damage. In addition to the laboratory data on consumption, for the estimation of the potential yield losses due to Orthoptera, other insect-caused damage, such as cutting off of plant parts without consuming them (Holmberg \& Hardman, 1984) and the fact that Orthoptera can increase their body temperature above ambient by means of thermoregulation (Begon, 1983; Willott, 1997), need to be taken into consideration.

ACKNOWLEDGEMENTS. The authors would like to thank I. Lytra and V. Evangelou for their assistance with the laboratory experiments and P. Milonas for his helpful criticism of the manuscript. We also thank the two anonymous reviewers for their constructive suggestions.

\section{REFERENCES}

AKMAN GüNDÜZ N.E. \& GÜLEL A. 2002: Effect of temperature on development, sexual maturation time, food consumption and body weight of Schistocerca gregaria Forsk. (Orthoptera: Acrididae). - Turk. J. Zool. 26: 223-227.

Ávila C.J. \& PARra J.R.P. 2003: Leaf consumption by Diabrotica speciosa (Coleoptera: Chrysomelidae) adults on different host plants. - Sci. Agric. 60: 789-792.

BAILEY C.G. \& MuKeRJI M.K. 1976: Consumption and utilization of various host plants by Melanoplus bivittatus Say and M. femurrubrum De Geer (Orthoptera: Acrididae). Can. J. Zool. 54: 1044-1050.

Bardi C., Mariottini Y., De Wysiecki M.L. \& Lange C.E. 2011: Postembryonic development fecundity and food consumption of Dichroplus exilis (Orthoptera: Acrididae) under controlled conditions. - Rev. Biol. Trop. 59: 1579-1587.

BEGON M. 1983: Grasshopper population and weather: the effect of insolation on Chorthippus brunneus. - Ecol. Entomol. 8 : 361-370.

Bei-Bienko G.YA. \& Mischenko L.L. 1963: Locusts and Grasshoppers of the U.S.S.R. and Adjacent Countries. Part 1. Israel program for scientific translations, $400 \mathrm{pp}$. (translated from Russian).

Bell A.A. 1986: Physiology of secondary products. In Mauney J.R. \& Stewart J. McD. (eds): Cotton Physiology. The Cotton Foundation, Memphis, TN, pp. 597-621.

Bernays E.A. \& Chapman R.F. 1977: Deterrent chemicals as a basis of oligophagy in Locusta migratoria (L). - Ecol. Entomol. 2: 1-18.

Blanchet E., Pages C., Blondin L., Billot C., Rivallan R., VASSAL J.M., LecoQ M. \& Risterucci A.M. 2010: Isolation of microsatellite markers in the Calliptamus genus (Orthoptera, Acrididae). - J. Insect Sci. 10: Article 133.

Blanchet E., Lecol M., Sword G.A., Pages C., Blondin L., Billot C., Rivallan R., Foucart A., Vassal J.M., Risterucci A.M. \& Chapuis M.P. 2012: Population structures of three Calliptamus spp. (Orthoptera: Acrididae) across the Western Mediterranean Basin. - Eur. J. Entomol. 109: 445-455.

Chapman R.F. 1998: The eggs and embryology. In Chapman R. F. (ed.): The Insects: Structure and Function. Cambridge University Press, Cambridge, pp. 325-360.

CooK A.G. 1977: Nutrient chemicals as phagostimulants for Locusta migratoria (L.). - Ecol. Entomol. 2: 113-121.
De Faria M., Almeida D. \& Magalhães B. 1999: Food consumption of Rhammatocerus schistocercoides Rehn (Orthoptera: Acrididae) infected by the fungus Metarhizium flavoviride Gams \& Rozsypal. — An. Soc. Entomol. Bras. 28: 91-99.

Deliorman-Orhan D., Orhan N., Ozcelik B. \& Ergun F. 2009: Biological activities of Vitis vinifera L. leaves. - Turk. J. Biol. 33: 341-348.

Evans E.W., Rogers R.A. \& Opferman D.J. 1983: Sampling grasshoppers (Orthoptera: Acrididae) on burned and unburned tallgrass prairie: night trapping vs sweeping. - Environ. Entomol. 12: 1449-1454.

FAOSTAT 2012: http://faostat.fao.org.

Ferro D.N., Logan J.A., Voss R.H. \& Elkinton J.S. 1985: Colorado potato beetle (Coleoptera: Chrysomelidae) temperature-dependent growth and feeding rates. - Environ. Entomol. 14: 343-348.

Gentry J.W. 1965: Crop Insects of Northeast Africa - Southwest Asia. Agriculture Handbook No. 273, Agricultural Research Service, U.S. Department of Agriculture, Washington D.C., 210 pp.

Hewitt G.B. \& Onsager R.J. 1983: Control of grasshopper on rangeland in the United States, a perspective. - J. Range Manag. 36: 202-207.

Hoekstra A. \& Beenakkers M.Th. 1976: Consumption, digestion and utilization of various grasses by fifth-instar larvae and adults of migratory locust. - Entomol. Exp. Appl. 19: 130-138.

Holmberg R.G. \& Hardman J.M. 1984: Relating feeding rates to sex and size in six species of grasshoppers (Orthoptera: Acrididae). - Can. Entomol. 116: 597-606.

InGRISCH S. \& KöHLER G. 1998: Die Heuschrecken Mitteleuropas. Westarp Wissenschaften, Magdeburg, $460 \mathrm{pp}$.

JoHnson D.L. \& MüNDEL H.H. 1987: Grasshopper feeding rates, preferences, and growth on safflower. - Ann. Appl. Biol. 111: $43-52$.

Johnson D.L. \& PaVlikova E. 1986: Reduction of consumption by grasshoppers (Orthoptera: Acrididae) infected with Nosema locustae Canning (Microsporida: Nosematidae). - J. Invert. Pathol. 48: 232-238.

Kolbe H. \& Stephan-Beckmann S. 1997a: Development, growth and chemical composition of the potato crop (Solanum tuberosum L.). I. Leaf and stem. - Potato Res. 40: 111-129.

Kolbe H. \& Stephan-Beckmann S. 1997b: Development, growth and chemical composition of the potato crop (Solanum tuberosum L.). II. Tuber and whole plant. - Potato Res. 40: 135-153.

LACTIN J.D. \& Johnson D.L. 1995: Temperature-dependent feeding rates of Melanoplus sanguinipes nymphs (Orthoptera: Acrididae) in laboratory trials. - Environ. Entomol. 24: 1291-1296.

LATCHININSKY V.A. 1998: Moroccan locust Dociostaurus maroccanus (Thunberg, 1815): a faunistic rarity or an important economic pest? - J. Insect Conserv. 2: 167-178.

Levesque K.R., Fortin M. \& Mauffette Y. 2002: Temperature and food quality effects on growth, consumption and postingestive utilization efficiencies of the forest tent caterpillar Malacosoma disstria (Lepidoptera: Lasiocampidae). - Bull. Entomol. Res. 92: 127-136.

Logan P.A., Casagrande R.A., Faubert H.H. \& Drummond F.A. 1985: Temperature-dependent development and feeding of immature Colorado potato beetles, Leptinotarsa decemlineata (Say) (Coleoptera: Chrysomelidae). - Envir. Entomol. 14: 275-283.

Mariottini Y., De Wysiecki M.L. \& Lange C.E. 2011: Postembryonic development and food consumption of Dichroplus 
elongates Giglio-Tos and Dichroplus maculipennis (Blanchard) (Orthoptera: Acrididae: Melanoplinae) under laboratory conditions. - Neotrop. Entomol. 40: 190-196.

MCCAFFERY A.R. 1975: Food quality and quantity in relation to egg production in Locusta migratoria. - J. Insect Physiol. 21: $1551-1558$.

MCKINLEY K.S. \& RANDELL R.L. 1971: Moisture content and the nutritional value of laboratory diets for the migratory grasshopper, Melanoplus sanguinipes (Orthoptera: Acrididae). Can. Entomol. 103: 657-661.

Milonas P.G. \& Savopoulou-Soultani M. 2000: Development, survivorship, and reproduction of Adoxophyes orana (Lepidoptera: Tortricidae) at constant temperatures. - Ann. Entomol. Soc. Am. 93: 96-102.

Pedigo L.P., Hutchins S.H. \& Higley L.G. 1986: Economic injury levels in theory and practice. - Annu. Rev. Entomol. 31: 341-368.

Pelekasis K. 1976: Courses of Agricultural Entomology. Vol. A. Morphology Systematic. AGSA, Athens, pp. 219-243.

RifFAT S. \& Wagan M.S. 2007: The effect of food plants on the growth rate, fecundity and survivability of grasshopper Hieroglyphus nigrorepletus I. Bolivar (Orthoptera: Acrididae) a major paddy pest in Pakistan. - J. Biol. Sci. 7: 1282-1286.

Ryszkowski L., Karg J., Margarit G., Paoletti M.G. \& Glotin R. 1993: Above-ground insect biomass in agricultural landscape of Europe. In Bunce R.G.H., Ryszkowski L. \& Paoletti M.G. (eds): Landscape Ecology and Agroecosystems. Lewis, Boca Raton, FL, pp. 71-82.

SAS Institute Inc. 2007: JMP, Version 7.0.1. Cary, NC.

Schmidt G.H. \& Albutz R. 1994: Laboratory studies on pheromones and reproduction in the Desert Locust Schistocerca gregaria (Forsk.). - J. Appl. Entomol. 118: 378-391.

Sharpe P.J.H., Curry G.L., DeMichele D.W. \& Cole C.L. 1977: Distribution model of organism development times. J. Theor. Biol. 64: 649-670.

Shields E.J., Rouse D.I. \& Wyman J.A. 1985: Variegated cutworm (Lepidoptera: Noctuidae): leaf area consumption, feeding site preference and economic injury level calculation for potatoes. - J. Econ. Entomol. 78: 1095-1099.

SHower A.T. 1995: Locust (Orthoptera: Acrididae) outbreak in Africa and Asia, 1992-1994: an overview. - Am. Entomol. 41: 179-185.

Sмith D.S. \& Holmes N.D. 1977: The distribution and abundance of adult grasshoppers (Acrididae) in crops in Alberta, 1918-1975. - Can. Entomol. 109: 575-592.

Syed T.S., Lal M., Abro G.H. \& SiddiQui S. 2011: Effect of consumption of different hosts on the body weight of surface grasshopper, Chrotogonus trachypterus Lanchard (Orthoptera: Pyrgomorphidae). — Sarhad J. Agric. 27: 245-249.

SzÖVÉNYI G. 2002: Qualification of grassland habitats based on their Orthoptera assemblages in the Közeg Mountains (W-Hungary). - Entomol. Exp. Appl. 104: 159-163.

Walker M.P., Lewis C.J. \& Whitman D.W. 1999: Effects of males on the fecundity and fertility of female Romalea microptera grasshoppers. - J. Orthopt. Res. 8: 277-283.

WANG J. \& TSAI J.H. 2000: Effect of temperature on the biology of Aphis spiraecola (Homoptera: Aphididae). - Ann. Entomol. Soc. Am. 93: 874-883.

WhitMAn D.W. 1986: Developmental thermal requirements for the grasshopper Taeniopoda eques (Orthoptera: Acrididae). - Ann. Entomol. Soc. Am. 79: 711-714.

Wigglesworth V.B. 1974: The Principles of Insect Physiology. Chapman and Hall, London, 827 pp.

WiLLEMSE F. \& WiLlemSE L. 2008: An annotated checklist of the Orthoptera-Saltatoria from Greece, including an updated bibliography. - Articulata (Beiheft) 13: 1-91.

WiLlotT S.J. 1997: Thermoregulation in four species of British grasshoppers (Orthoptera: Acrididae). - Funct. Ecol. 11: 705-713.

WiLlott S.J. \& Hassal M. 1998: Life-history responses of British grasshoppers (Orthoptera: Acrididae) to temperature change. - Funct. Ecol. 12: 232-241.

Received March 8, 2013; revised and accepted April 29, 2013 